\title{
Rapid In vitro Root Induction in Transgenic Cotton Shoots
}

\author{
Bushra Rashid*, Tayyab Husnain and S. Riazuddin \\ Centre of Excellence in Molecular Biology, University of the Punjab, Lahore-53700, \\ Pakistan
}

Key words: Gossypium hirsutum, Rooting, Transgenic cotton

An efficient in vitro rooting technique was developed for recovery of transgenic cotton plants. The loss of transgenic shoots due to failure to form roots is genotype dependant and represents a significant limiting factor in the overall recovery of transgenic plants from cultures. Transgenic shoots following selection on antibiotic medium were efficiently rooted on MS containing different combinations of kinetin, IBA and IAA. Healthy and efficient rooting was achieved when the shoots with blackish and dead root portion were treated with $1.0 \mathrm{mg} / \mathrm{ml} \mathrm{IBA}$ and cultured on MS medium containing $2 \%$ sucrose. This method for in vitro rooting of cotton shoots proved to be a simple and reliable allowing $98 \%$ recovery of non-rooting shoots from culture. All the rooted plants normally survived in soil and flowered.

Cotton crop has been difficult to manipulate with high efficiency since the tissue culture methods used for regenerating transgenic plants by indirect transformation via callus. So, in vitro regeneration by somatic embryogenesis is limited to a few cultivars (Price and Smith 1979, Davidonis and Hamilton 1983, Shoemaker et al. 1986, Trolinder and Goodin 1988a, Finer 1988, Firoozabady and DeBoer 1993, Gawel and Robacker 1990, Rajasekaran et al. 1996, Hazra et al. 2000, Mishra et al. 2003, Sakhanokho et al. 2004 and Haq 2005). Tissue culture is not only a theoretical prerequisite for plant transformation, but it is employed in almost all transformation systems to achieve a suitable efficiency of gene transfer, selection, and regeneration of transformants.

Rooting in transgenic cotton plants is a major limiting factor, so whatever be the transformation system used, all methods ultimately depend on root formation for the recovery of plants from culture (Luo and Gould 1999). Genotype, position of explants, components of medium and proportion of phytohormone will influence plant regeneration. In the present findings, the root portion in transgenic shoots after selection on antibiotic medium was getting black and ultimately shoots died. In this report a more efficient and simple

*Author for correspondence.<bush_rashid@yahoo.com>. 
procedure for rooting of transgenic cotton plants on the tissue culture media has been described. We made modifications to the procedures (Gould et al. 1991, Hemphil et al. 1998, Kumria et al. 2003, Sakhanokho et al. 2004 and Ouma et al. 2005). Modifications were related to the growth hormone regime, sucrose level and the procedure to culture the plantlets at rooting stage.

Different concentrations i.e. 1, 1.5, 2, 2.5 and 3\% of sucrose were added to MS medium. Plant growth regulators were added to the medium in combinations or separately as $\mathrm{Kn}(1 \mathrm{mg} / \mathrm{l})$, IAA $(1 \mathrm{mg} / \mathrm{l})$, and IBA $(1 \mathrm{mg} / \mathrm{l})$. Then $\mathrm{pH}$ was adjusted to 5.7 - 5.8 and medium was sterilized at $121^{\circ} \mathrm{C}$ and $15 \mathrm{lbs}$ psi for $20 \mathrm{~min}$. Transformed shoots of cotton variety CIM- 482 with black and dead root portion were cultured on this modified medium. Another modification was made that the dead and black root portion was cut with a surgical blade and the base of the shoot was just dipped in solution of IBA $(1 \mathrm{mg} / \mathrm{l})$ and then cultured on simple MS. The cultures were kept at $27 \pm 2{ }^{\circ} \mathrm{C}$ with a photoperiod of $16 \mathrm{~h}$ under the light regime, $100-120 \mu \mathrm{m} \mathrm{m}^{2} / \mathrm{s}$.

Rooted shoots were taken out of the culture vessel and the medium was removed by washing roots with water. The root portion was dipped into solution of IBA (1 mg/l) and planted into the soil pots (Rashid et al. 2004). Nontransformed plantlets were shifted to soil without IBA treatment. Pots were covered with polythene bags after adding $20-25 \mathrm{ml}$ of nutrient solution and kept at $30 \pm 2{ }^{\circ} \mathrm{C}$ for $16 \mathrm{hr}$ photoperiod in light intensity of $250-300 \mu \mathrm{mol} / \mathrm{m}^{2} / \mathrm{s}$ and removed completely after acclimation of plants.

Table 1. Effect of growth hormones on rooting of transgenic shoots.

\begin{tabular}{lc}
\hline Growth hormones (mg/l) & Rooting (\%) \\
\hline MS + Kn (1.00) + (IAA 1.00) & 45 \\
MS + Kn (1.00) + IBA (1.00) & 77 \\
MS + IAA (1.00) & 52 \\
MS + IBA (1.00) & 80 \\
IBA 1.00 (Black root cut and treated with IBA) & 98 \\
MS (Transgenic) & 0 \\
MS (Non-transgenic) & 92 \\
\hline
\end{tabular}

Non-transgenic plants formed $92 \%$ roots on MS. IBA alone or in combination with $\mathrm{Kn}$ showed rooting in 80 and $77 \%$, respectively. IAA is a weak auxin and formed 45 and $52 \%$ rooting in combination with $\mathrm{Kn}$ or alone (Table 1). When dead and black root was cut and treated with IBA solution and again cultured on MS, it formed $98 \%$ rooting within one week (Fig. 1). Treating roots with IBA before shifting to soil helped the plants establish well into the soil. Similar 
technique with some modifications was used by Hemphil et al. (1998). So, to achieve rooting of the transgenic plants IBA is the best treatment alone or in combination with other hormones.

Sucrose at $2 \%$ with the combinations of growth hormones produced $95 \%$ rooting. Low rooting was obtained on $3 \%$ sucrose even with the combinations of growth hormones. Most of the reports suggested lowering the concentrations of sucrose or glucose than the standard MS medium i.e. 3\% at the time of rooting (Smith et al. 1977, Davidonis and Hamilton 1983, Shoemaker et al. 1986, Ouma et al. 2004, Sakhanokho et al. 2004). Plants with well developed roots survived

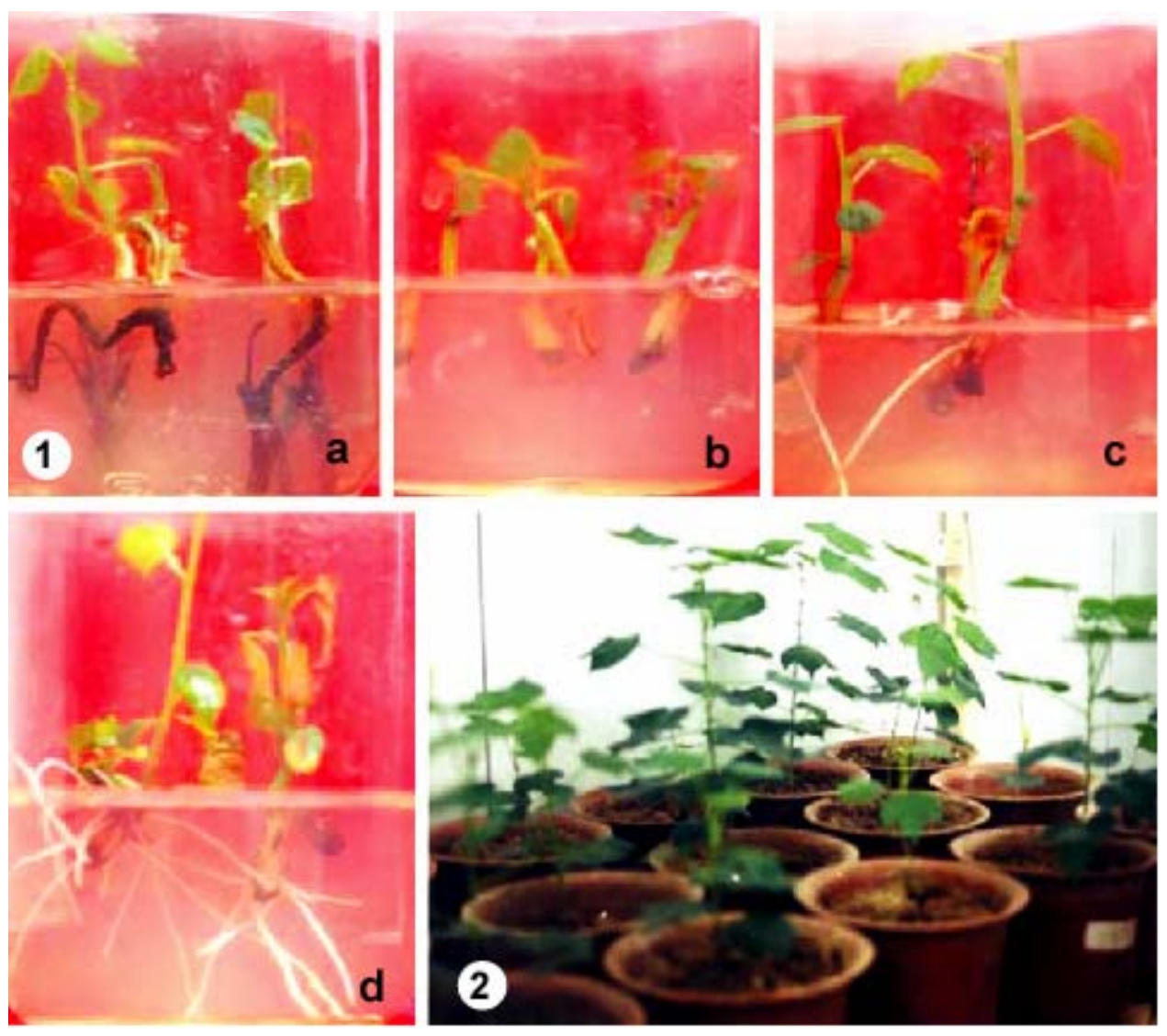

Figs.1-2: 1. Rooting of transgenic cotton plants. (a) Black roots in transgenic shoots. (b) Roots treated with IBA $(1 \mathrm{mg} / \mathrm{l})$. (c) Root formation started after IBA treatment. (d) Well developed roots after $10-15$ days. 2. Transgenic cotton plants were kept at 28 $30^{\circ} \mathrm{C}$, under light intensity of $250-300 \mu \mathrm{mol} / \mathrm{m}^{2} / \mathrm{s}$ and humidity $60 \%$.

normally into the soil, flowered normally and fertile seeds were collected (Fig. 2). By this protocol the overall transformation process was reduced from 1 year (Firoozababy et al. 1987, Umbeck et al. 1987) to four - five months (Jin et al. 2005). 
The sucrose concentrations at 1, 1.5, 2, 2.5 and $3 \%$ showed 30, 52, 95, 61 and 00 percentage of root development, respectively in transgenic shoots.

\section{References}

Davidonis GH and Hamilton RH (1983) Plant regeneration from callus tissue of Gossypium hirsutum L. Plant Sci. Lett. 32: 89-93.

Finer JJ (1988) Plant regeneration from somatic embryogenic suspension cultures of cotton (Gossypium hirsutum L). Plant Cell Reports 7: 399-402.

Firoozabady E, De Boer DL, Merlo DJ, Halk EL, Amerson LN, Rashka KE and Elizabeth EM (1987) Transformation of cotton (Gossypium hirsutum L.) by Agrobacterium tumefaciens and regeneration of transgenic plants. Plant Mol. Biol. 10: 105-116.

Firoozabady E and DeBoer DL (1993) Plant regeneration via somatic embryogenesis in many cultivars of cotton (Gossypium hirsutum L.). In Vitro Cell. Dev. Biol. Plant 29: 166-173.

Gawel N and Robacker CD (1990) Genetic control of somatic embryogenesis in cotton petiole callus cultures. Euphytica 49: 249-253.

Gould JH, Banister S, Hasegawa O, Fahima M and Smith RH (1991) Regeneration of Gossypium hirsutum and G. barbadense from shoot apex tissue for transformation. Plant Cell Reports 10: 12-16.

Haq Ikramul (2005) Callus proliferation and somatic embryogenesis in cotton (Gossypium hirsutum L.). African J. Biotechnol. 4: 206-209.

Hazra S, Kulkarni AV, Nalawade SM, Banerjee AK, Agrawal DC and Krishnamurthy KV (2000) Influence of explants, genotypes and culture vessels on sprouting and proliferation of pre-existing meristems of cotton (Gossypium hirsutum L. and Gossypium arboreum L.). In Vitro Cell. Dev. Biol. Plant 36: 505-510.

Hemphill JK Maier CG and Chapman KD (1998) Rapid in vitro plant regeneration of cotton (Gossypium hirsutum L) Plant Cell Rep. 17: 273-278.

Jin S, Zhang X, Liang S, Nie Y, Guo X and Huang C (2005) Factors affecting transformation efficiency of embryogenic callus of Upland cotton (Gossypium hirsutum) with Agrobacterium tumefaciens. Plant Cell Tiss. Org. Cult. 81: 229-237.

Kumria R, Sunnichan VG, Das DK, Gupta SK, Reddy VS, Bhatnagar RK and Leelavathi S (2003) High-frequency somatic embryo production and maturation into normal plants in cotton (Gossypium hirsutum) through metabolic stress. Plant Cell Reports 21: 635-639.

Luo J and Gould JH (1999) In vitro shoot-tip grafting improves recovery of cotton plants from culture. Plant Cell Tiss. Org. Cult. 57: 211-213. 
Mishra R, Wang HY, Yadav NR and Wilkins TA (2003) Development of a highly regenerable elite Acala cotton (Gossypium hirsutum cv. Maxxa) a step towards genotype-independent regeneration. Plant Cell Tiss. Org. Cult. 73: 21-35.

Ouma JP, Young MM and Reichert NA (2004) Rooting of in vitro regenerated cotton (Gossypium hirsutum L) is influenced by genotype, medium composition, explant type and age. African J. Biotechnol. 3: 313-318.

Price HJ and Smith RH (1979) Somatic embryogenesis in suspension cultures of Gossypium koltzschianum Andress. Planta 145: 305-307.

Rajasekaran K, Grula JW, Hudspeth RL, Pofelis S and Anderson DM (1996) Herbicideresistant Acala and Coker cottons transformed with a native gene encoding mutant forms of acetohydroxyacid synthase. Mol. Breed. 2: 307-319.

Rashid B, Husnain T and Riazuddin S (2004) In vitro shoot tip culture of cotton (Gossypium hirsutum). Pak. J. Bot. 36(4): 817-824

Sakhanokho HF, Ozias-Akins P, May OL and Chee PW (2004) Induction of somatic embryogenesis and plant regeneration in select Georgia and Pee Dee Cotton Line. Crop Sci. 44: 2199-2205.

Shoemaker RC, Couche LJ and Galbraith DW (1986) Characterization of somatic embryogenesis and plant regeneration in cotton. (Gossypium hirsutum L.) Plant Cell Reports 3: 178-181.

Smith RH, Price HJ and Thaxton JB (1977) Defined conditions for the initiation and growth of cotton callus in vitro. I. Gossypium arboreum. In Vitro 13: 329-334.

Trolinder NL and Goodin JR (1988a) Somatic embryogenesis in cotton (Gossypium) 1. effects of source of explant and hormone regime. Plant Cell Tiss. Org. Cult. 12: 31-42.

Umbeck P, Johnson G, Barton K and Swain W (1987) Genetically transformed cotton (Gossypium hirsutum L.) plants. Bio/Technol. 5: 263-266. 